\title{
Analysis of an Active Charge Balancing Method Based on a Single Non-Isolated DC/DC Converter
}

\author{
Manuel Raeber, Member, IEEE, Andreas Heinzelmann, Djaffar Ould Abdeslam, Senior Member, IEEE
}

\begin{abstract}
For lithium-ion batteries, active balancing can bring advantages compared to passive balancing in terms of lifetime and available capacity. Most known balancing techniques suffer from a low efficiency or high complexity and cost. This paper proposes a new technical solution based on a non-isolated DC/DC converter and a low-speed switching matrix to overcome efficiency and power limitations of present balancing methods. The proposed circuit allows balancing current paths which are not possible with previous methods and results in balancing efficiencies of over $\mathbf{9 0 \%}$. The performance comparison is based on batch numerical simulations using calculated and measured efficiency values. The simulation results are compared to the approved active balancing method cell-to-cell and to passive balancing. A study case with eight randomly distributed battery cells shows an improvement in overall balancing efficiency of up to $47.4 \%$ and a reduction in balancing time of up to $36.9 \%$. The available capacity increases from $97.2 \%$ in a passively balanced system to $99.7 \%$ for the new method. A hardware prototype was set up to demonstrate the working principle and to verify the numerical simulations.
\end{abstract}

Index Terms - Active balancing, Battery management system, Lithium-ion batteries

\section{INTRODUCTION}

$\mathrm{L}$ ARGE lithium ion batteries consist of many single cells that are connected in series and in parallel to deliver the desired system voltage and energy capacity. The electric parameters of individual cells vary due to fabrication tolerances, initial charge, ageing and temperature gradients inside the battery pack. Because the cells are connected in series, the usable capacity of a battery system is limited by its weakest cell or cell level. Any remaining charge in the other cells stays untouched. During charging, the weakest cell reaches the over voltage limit first, forcing a reduction of the charging current down to the rated balancing current.

Since the beginning of the use of lithium-ion technology, balancing circuits ensure that battery systems always operate in the safe area. Passive balancing helps to equalize the cells and increases the lifetime. Active balancing circuits were first proposed in the early $21^{\text {th }}$ century in [1], [2] and [3]. Now it was possible to transfer charge between individual cells at high

Manuscript received April 4, 2019; revised July 24 2019, October 16, 2019, and November 17, 2019; accepted January 22, 2020.

M. Raeber is with the University of Applied Sciences ZHAW, Technikumstrasse 9, 8400 Winterthur, Switzerland and also with the IRIMAS Institute, University of Haute Alsace, 61 rue Albert Camus, Mulhouse, France (e-mail: aee@zhaw.ch).

A. Heinzelmann is with the University of Applied Sciences ZHAW, Technikumstrasse 9, 8400 Winterthur, Switzerland (e-mail: andreas.heinzelmann@zhaw.ch)

D. Ould Abdeslam is with the IRIMAS Institute, University of Haute Alsace, 61 rue Albert Camus, Mulhouse, France (e-mail: djaffar.ouldabdeslam@uha.fr). efficiency. Apart from accelerating the balancing process significantly, they also represent a possibility to enhance the energy efficiency and eco friendliness of lithium-ion battery systems when applied during both charging and discharging. Charge, which would stay unused in the cell, is transferred to another, weaker cell. This leads to an increase of the usable capacity of the battery. Commonly, four basic topologies are distinguished [4]: Cell-to-cell, cell-to-stack, stack-to-cell and stack-to-cell-to-stack, which is a combination of the previous two. In Fig. 1 these four main topologies are shown. The cellto-null method describes the common implementation of passive balancing through resistive dissipation.

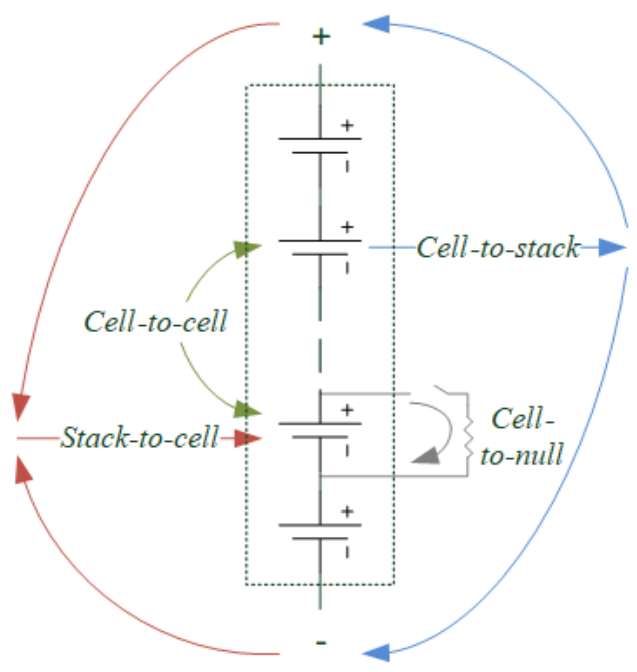

Fig. 1. Working principle of different active balancing methods

This paper demonstrates the use of a non-isolated DC/DCconverter and a switch-matrix as a new approach to active charge balancing in lithium-ion battery systems. It is the first to propose the combination of a low-speed switching matrix with a single non-isolated DC/DC converter without the use of external energy tanks such as supercapacitors. On the following pages, the functionality and the estimated performance of two design varieties of the new method are presented. Section II summarizes the state of art and relevant publications on the latest balancing methods. In Section III, the proposed circuit is described in detail. The method including the numerical simulation settings, the balancing algorithm and the PLECS (Piecewise linear electric circuit simulation) system simulation are specified in Section IV. Section V presents the hardware prototype. The simulation results and a comparison of the proposed method to existing ones in terms of complexity and balancing performance are shown in Section VI. The paper concludes with a summary in Section VII. 


\section{STATE OF ART}

Many different methods and circuits for active charge balancing were discussed in the literature in recent years. Reviews and a general topology overview are available in [4], [5] and [6]. The superiority of active balancing over passive balancing in terms of energy efficiency and balancing speed has been proven in theory ([6], [7], [8]) and by measurement ([9], [10], [11], [12]). Most authors focus on the methods shown in Fig. 1, which often include isolated power supplies. Apart from these methods, other circuits and types have been proposed, e.g. cell bypassing in [12], [13], [14], [15] and the use of a floating capacitor or battery as a charge buffer in [16], [17], [18] and [19]. Complete decoupling of the battery system and the load can be achieved by using an individual converter for each cell as shown in [20]. In [21], design guidelines are available for switched inductor balancing including MOSFET selection. depending on the cell and system parameters. A general theoretical analysis of active balancing performance is available in [22]. There, equations as a function of cell number, efficiency and capacity distribution are given for active balancing circuits.

Electronic circuits for balancing with non-isolated power converters and a MOSFET switch matrix were proposed in [16], [17], [18] and [19]. They are not capable of continuous balancing due to their unidirectional power flow and require a converter with a current ratio of twice the resulting balancing current. Another solution are PWM converters ([23]), single switched inductor circuits ([24], [25]) and single switched capacitor circuits ([17], [26]). All these techniques require a high switching frequency associated with high MOSFET driving effort and switching losses. Commercially available solutions for active balancing include bidirectional flyback transformers (LT, cell-to-stack-to-cell) and a single bidirectional converter with a switch matrix (TI, cell-to-cell).

TABLE I shows an overview of balancing prototypes realized in hardware and the measured balancing efficiency and current. Non-isolated types are in the focus of interest as they compete directly with the methods presented in this work.

TABLE I

OVERVIEW OF ACTIVE BALANCING METHODS

\begin{tabular}{llll}
\hline \hline Architecture & $\begin{array}{l}\text { Max. } \\
\text { balancing } \\
\text { current }\end{array}$ & $\begin{array}{l}\text { Max. } \\
\text { balancing } \\
\text { efficiency }\end{array}$ & $\begin{array}{l}\text { Uses } \\
\text { isolated } \\
\text { converter }\end{array}$ \\
\hline Switched inductor [24] & $0.8 \mathrm{~A}$ & $80 \%$ & No \\
Single switched capacitor [17] & $2 \mathrm{~A}$ & $83 \%$ & No \\
Supercapacitor converter [27] & $1 \mathrm{~A}$ & $90 \%$ & No \\
Supercapacitor converter [28] & $10 \mathrm{~A}$ & $85 \%$ & No \\
Bidirectional forward converter [18] & 4 A & $72-90 \%$ & No \\
Switched inductors [29] & $1 \mathrm{~A}$ & $\mathrm{~N} / \mathrm{A}$ & No \\
Switched inductors [30] & 5 A & $85 \%$ & No \\
Switched coupled inductors [31] & $1 \mathrm{~A}$ & $90 \%$ & No \\
PWM converters [23] & $0.5 \mathrm{~A}$ & $92 \%$ & No \\
Cell bypass [32] & N/A & $>90 \%$ & No \\
Multiple flyback converters [33] & $1.5 \mathrm{~A}$ & $80 \%$ & Yes \\
Multi-windings transformer [34] & 4 A & $90 \%$ & Yes \\
Multi-windings transformer [35] & $2 \mathrm{~A}$ & $81 \%$ & Yes \\
Multiple transformers [36] & 4 A & $88 \%$ & Yes \\
Switched transformer [10] & 0.25 A & $70 \%$ & Yes \\
Switched transformer [37] & 2 A & $81 \%$ & Yes \\
ZVS Converter [38] & $0.3 \mathrm{~A}$ & $89 \%$ & Yes \\
Bidirectional converters [37] & $2 \mathrm{~A}$ & $82 \%$ & Yes \\
Bidirectional converter [39] & 2 A & $80-93 \%$ & Yes \\
\hline \hline
\end{tabular}

The cited balancing circuits are designed for a few cells up to 16 cells in series. For higher voltage systems, module restricted balancing with the use of inter-module balancing as proposed in [24] is an option to maintain a reasonable balance between cost and performance.

\section{DESCRIPTION OF THE PROPOSED ELECTRONIC BALANCING CIRCUIT}

The balancing principle is based on selective charging and discharging of a variable number of battery cells connected in series. In discharge mode, the four-switch buck-boost converter works in buck mode and transfers charge from one cell or a multitude of adjacent cells to its subjacent cells in the stack. In charge mode, the converter works in boost mode to transfer charge in the opposite way. The input and output voltage range of the buck-boost converter must be wide enough to cover 1 to $n$ cells. Simultaneous balancing of multiple cells is only possible for adjacent cells.

The topology is shown in Fig. 2. It has a switch-matrix to connect the desired cells with the converter. The corresponding switches must be blocking in both directions and can be realized with 2 N-MOSFETs each. There are several possible implementations depending on the working modes and power direction of the converter. The current paths for a given balancing task (Discharge Cell 2 in Fig. 2) are colored in the overview schematics to illustrate the working principle. The buck converter delivers energy from Cell 1 and 2 through the switch $S w B 1$ and $S w A 1$ to Cell 1. Cell 1 and 2 are discharged with $I_{\text {Out }}$. Cell 1 is charged with the converter output current $I_{I n}$. Consequently, Cell 2 is discharged with $I_{O u t}$ A (negative balancing) and Cell 1 is charged with $\left(I_{I n}-I_{O u t}\right)$ A. The indices $i$ and $j$ define which cell positions are balanced. Here, $i=j=2$, because only one cell is balanced.

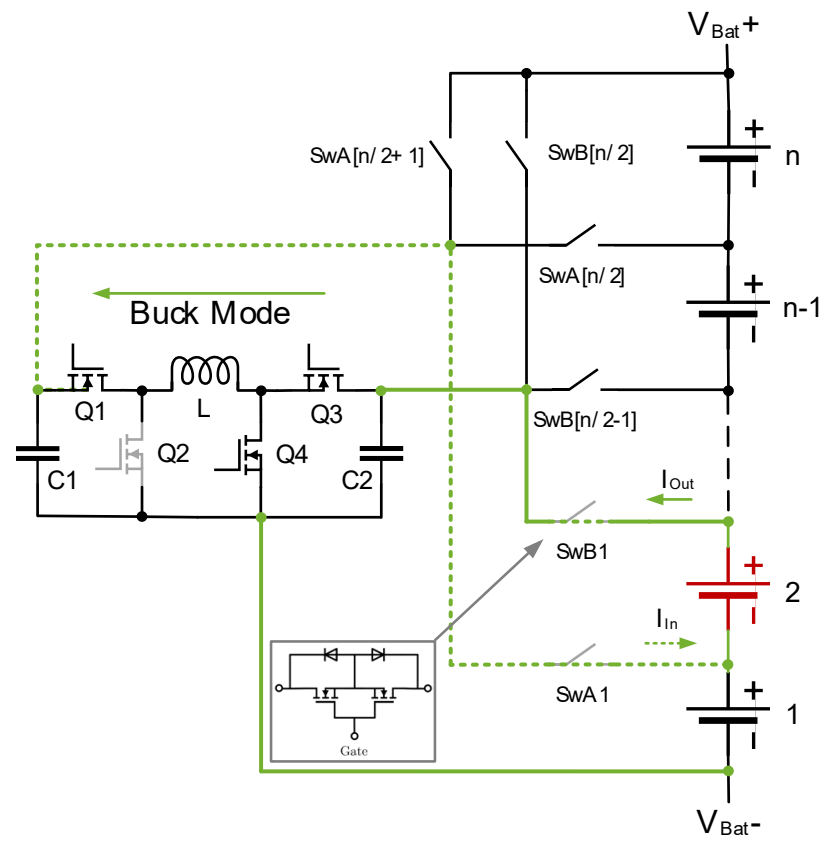

Fig. 2. Active balancing with buck converter and switch matrix (Negative balancing of Cell 2) for $n$ (even) cells

The transfer efficiencies are given as $\eta_{B u c k_{i j}}$ and $\eta_{B o o s t}{ }_{i j}$ (see 
TABLE III). The resulting cell current in idle mode can be expressed as a vector depending on the balancing current $I_{B a l}$ and the amount of balanced cells defined by $i$ and $j$ :

$$
\vec{I}_{\text {cell }}=\overrightarrow{I n} \cdot I_{\text {Bal }}-\eta \cdot \frac{\sum_{x=0}^{n} I n_{x}}{\sum_{y=0}^{n} \text { Out }} \cdot \overrightarrow{O u t} \cdot I_{B a l}
$$

The vectors $\overrightarrow{I n}$ and $\overrightarrow{O u t}$ are defined as follows for charging: $I n_{x}=1$ for $x \leq j$ and $I n_{x}=0$ for $j<x \leq n$, $O u t_{y}=1$ for $y<i$ and $O u t_{y}=0$ for $i \leq y \leq n$. and for discharging (negative balancing):

$I n_{x}=1$ for $x<i$ and $I n_{x}=0$ for $i \leq x \leq n$, $O u t_{y}=1$ for $y \leq j$ and $O u t_{y}=0$ for $j<y \leq n$.

The resulting efficiency of the balancing configurations for balancing adjacent cells $i$ to $j$ are given in (2) and (3). The two

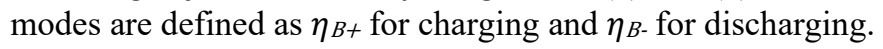

$$
\begin{aligned}
& \eta_{B+}=1-\frac{j \cdot \frac{1-\eta_{\text {Boost }_{i j}}}{\eta_{\text {Boost }_{i j}}}}{j-i+1}, \\
& \eta_{B-}=1-\frac{j \cdot\left(1-\eta_{\text {Buck }_{i j}}\right)}{j-i+1} .
\end{aligned}
$$

Fig. 3 shows the same system as in Fig. 2 but in boost mode. $Q 1$ is always on and $Q 2$ is inactive.

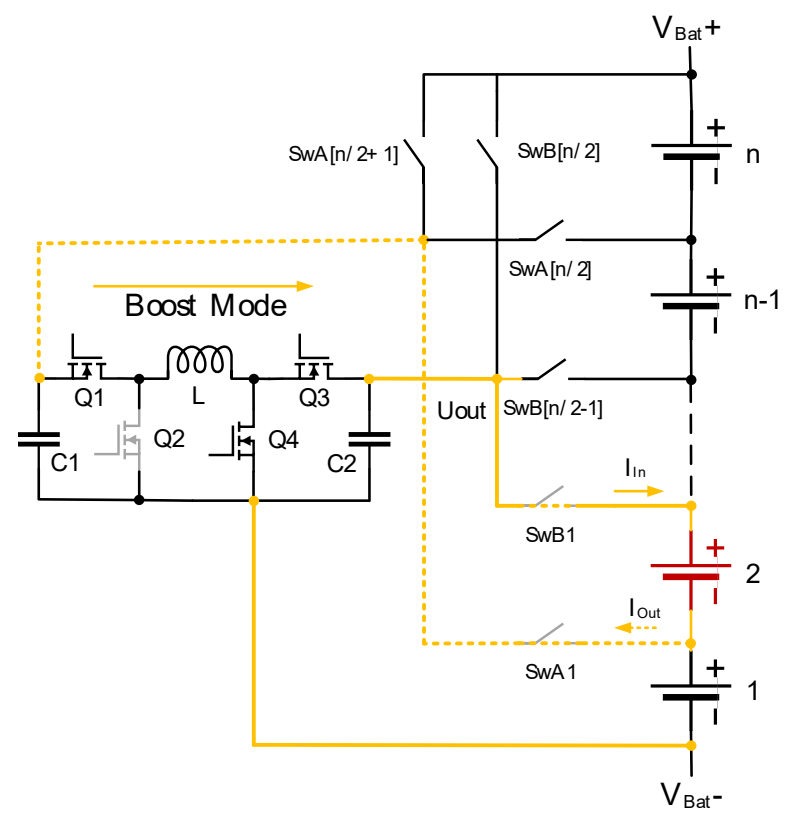

Fig. 3. Boost converter and switch matrix (Positive balancing of Cell 2)

\section{METHOD}

In this section, more information is given on the simulations and the balancing algorithm.

\section{A. Numerical simulation settings}

The numerical simulations were done in MATLAB. The cell capacity values are normally distributed numbers as a function of the chosen cell parameters (see TABLE II) as it is explained in [22]. The intention of the authors is to simulate the battery cell capacity distribution as realistic as possible. The balancing current value of $5 \mathrm{~A}$ is based on existing hardware specifications. A MATLAB script processes these values according to the specific balancing algorithm. The effective capacity of each cell $C_{\text {Cell }}(i)$ depends on the cell capacity and its SoC. Both values are handled as vectors according to (4):

$$
\vec{C}_{\text {Cell }}=\vec{C}_{\text {nom }} \cdot \overrightarrow{S o C}
$$

\section{B. Balancing algorithm used in the MATLAB simulation}

The balancing algorithm does not include SoC estimation. It requires information about the nominal cell capacities and $\mathrm{SoC}$ and uses the effective capacity $C_{\text {Cell }}$ for the calculation of the balancing paths. The flow chart is illustrated in Fig. 4. First, the parameters for $n$ cells are randomly generated according to the data in TABLE II. The cells are optionally sorted in ascending or descending order of their capacity. For a real battery system, this means that cells would have to be sorted before assembly. Then, the capacity difference of each cell to the mean value of all cells is calculated. Depending on the selected algorithm, "Simple" or "Smart", the cell or the group of adjacent cells with the maximum deviation from the mean value is selected for balancing. For algorithm "Simple" $i=j$ whereas for "Smart" $j \geq i$.

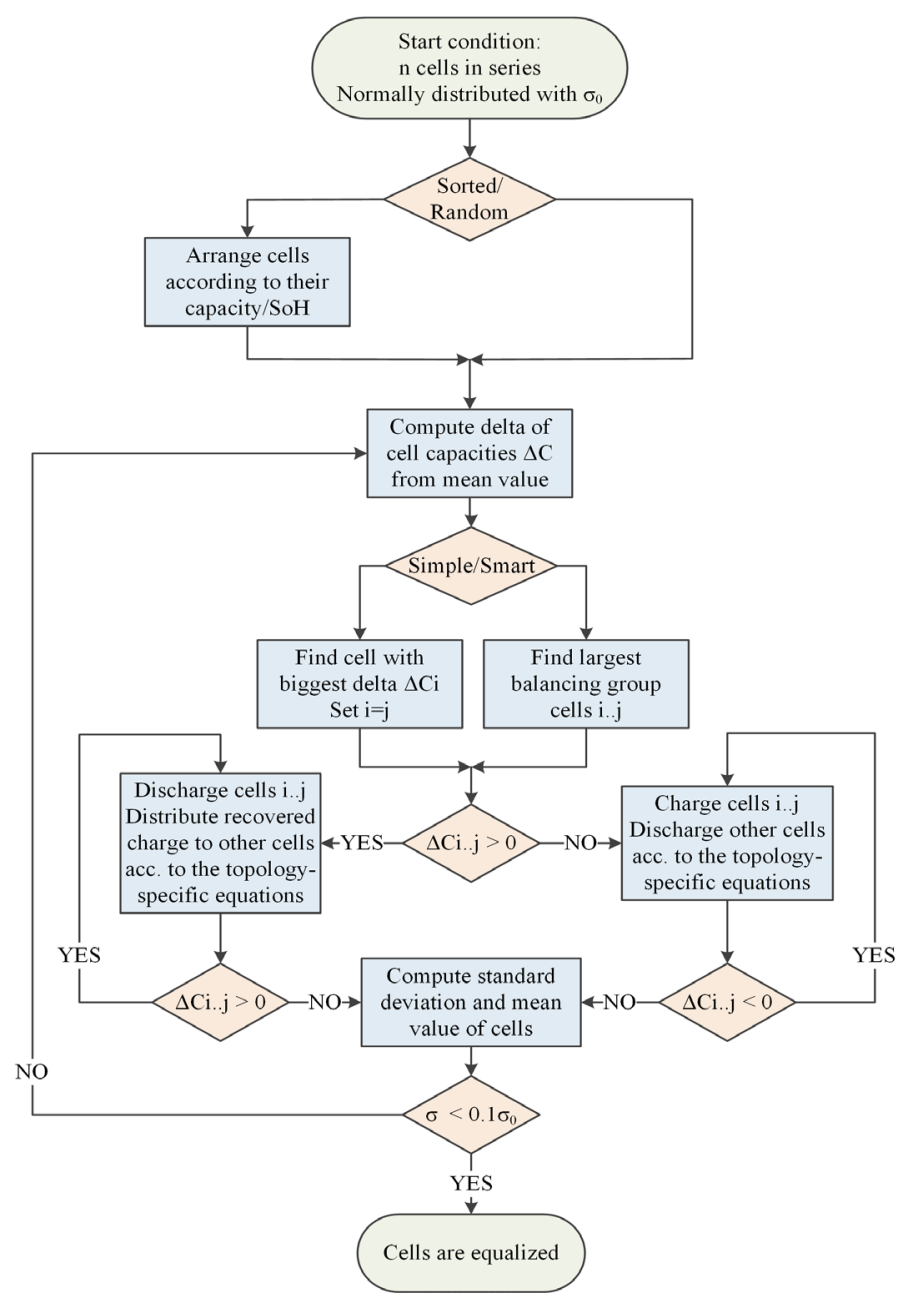

Fig. 4 Flow chart of the MATLAB algorithm for the simulation of the balancing process 
The following steps are repeated with a time step of $1 \mathrm{~s}$ :

- Charge or discharge the selected cell(s) by $I_{B a l}$ As (applying balancing for 1 second)

- Discharge or charge the cell(s) beneath the selected one with the resulting converter current from (1)

- Repeat the two previous steps until the capacity of one

TABLE II

SIMULATION PARAMETERS OF BATTERY CELLS

\begin{tabular}{lll}
\hline \hline Cell parameter & Symbol & Value \\
\hline Nominal capacity & $C_{n o m}$ & $10 \mathrm{Ah}$ \\
State of charge & SoC & $50 \%$ \\
Nominal voltage & $U_{n o m}$ & $3.2 \mathrm{~V}$ \\
Standard deviation of cell capacities & $\sigma_{0}$ & $2 \%$ \\
Number of cells & $n$ & 8 \\
Balancing current for: & & $5 \mathrm{~A}$ \\
Buck-boost (this work) & & $5 \mathrm{~A}$ \\
Reference method cell-to-cell & $I_{\text {Bal }}$ & $0.2 \mathrm{~A}$ \\
Passive Balancing & & \\
\hline \hline
\end{tabular}

of the active cells reaches the mean value

- Recalculate the mean and delta values and find the next cell or cell group to balance.

This sequence repeats until the deviation reaches less than $0.1 \sigma_{0}$. After 10,000 simulations of each parameter set, the mean value of all individual simulation results is computed.

\section{Converter efficiencies}

The efficiency values of the synchronous buck-boost converter are taken from measurements of the LT DC2596A evaluation board with added conduction losses of the switchmatrix (FET: Vishay SQJQ960EL) and given in TABLE III. Boost or buck operations from or to Cell 1 have a lower efficiency due to the low voltage level. For operations including

TABLE III

FOUR-SWITCH CONVERTER CHARACTERISTICS FOR ACTIVE BALANCING

\begin{tabular}{lcll}
\hline \hline $\begin{array}{l}\text { Transfer between } \\
\text { cell levels i and j }\end{array}$ & $\eta_{\text {Buck }}$ & $\eta_{\text {Boost }}$ & $\begin{array}{l}\text { Pmax } @ \mathrm{I}_{\text {Bal }}=5 \mathrm{~A} \text { and } \\
\mathrm{U}_{\text {Cell }}=3.6 \mathrm{~V}\end{array}$ \\
\hline From or to Cell 1 & 0.92 & 0.91 & $20 \mathrm{~W}$ \\
Any other cells & 0.97 & 0.965 & $130 \mathrm{~W}$ \\
\hline \hline
\end{tabular}

two or more cells the efficiency is higher and an average value of the measured efficiencies is used for the simulations.

For the reference method, the performance data of the TIDA00817 board was used. It is a cell-to-cell type active balancing board but uses an external battery as an energy tank and therefore the current flows not directly from one cell to another. An average transfer efficiency of $90 \%$ was assumed for both directions.

\section{System simulation settings}

In addition to the numerical simulations in MATLAB, a system simulation based on the "Simple" algorithm was set up in PLECS (MATLAB/Simulink). It includes the balancing efficiencies and algorithm presented earlier in this section. The buck/boost converter is modeled by two controllable current sources and the switch-matrix by ideal switches with $5 \mathrm{~m} \Omega$ onstate resistance. An RC-model has been used for the battery cells according to [40]. The cell type is lithium-ion with a nominal capacity of $10 \mathrm{Ah}$ and the balancing current is set to $5 \mathrm{~A}$. Since the switch-matrix is supposed to operate with slow switching speed, the minimum step size for state changes is $1 \mathrm{~s}$. The results of the system simulation are given in Section VI.D.

\section{HARDWARE PROTOTYPE}

The hardware implementation serves as a demonstration prototype to show the working principle of the presented balancing method. To facilitate the development process and increase the hardware versatility, a modularized design, consisting of a DC/DC converter, two switch-matrix units and an MCU board was chosen. Fig. 5 shows the test setup for the hardware measurements. Either lithium-ion or $\mathrm{LiFePO}_{4}$ cells can be used.

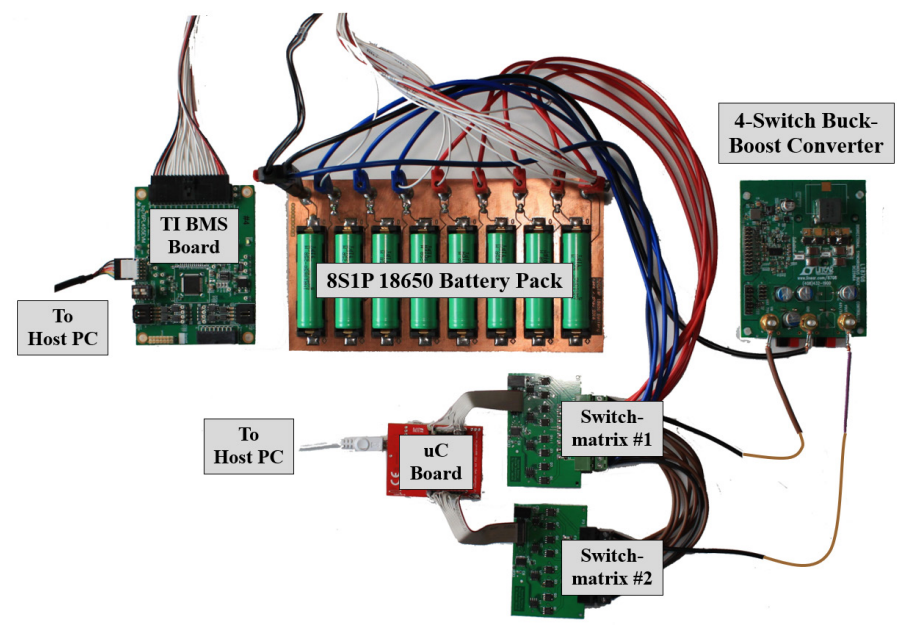

Fig. 6. Demonstration prototype with voltage monitoring board, MCU board, test battery, DC/DC converter and two switch-matrix units

\section{RESULTS}

In this section, the simulation results of the numerical simulations are presented in Section $A$ and $B$. Section $D$ shows the electrical simulation results whereas Sections $E$ and $F$ give the comparison of simulation and measurement.

\section{A. Battery cell equalization simulation}

Fig. 6 shows one simulation result of the balancing process during idle mode of the battery system. The circuit is simulated

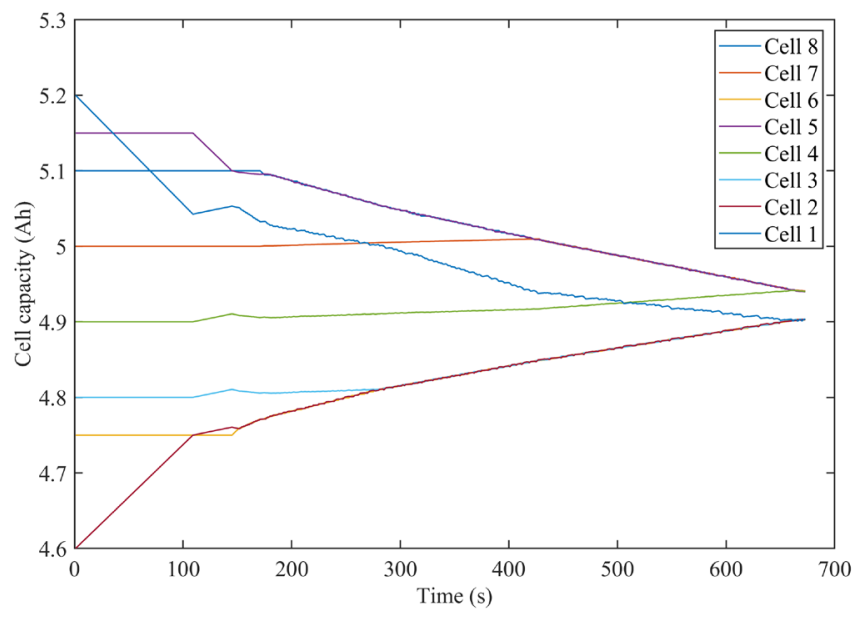

Fig. 5. Calculated balancing process for "Simple" algorithm of eight cells with battery cell capacities between $46 \%$ and $52 \%$ of $C_{n o m}$ 
here with eight battery cells with normally distributed cell capacities. An average cell capacity of $5 \mathrm{Ah}(50 \% \mathrm{SoC})$ and a standard deviation of $\sigma_{0}=2 \%$ is assumed. The algorithm achieves to reduce the charge imbalance continuously until the balancing process finishes after $680 \mathrm{~s}$ when $\sigma$ reaches $0.1 \sigma_{0}$.

Similar simulations are performed for other initial conditions and balancing algorithms. The output is used to calculate the average balancing time and efficiency in Section $B$.

\section{B. Energy efficiency and balancing speed}

The balancing performance of the evaluated circuit is compared to a reference method featuring a bidirectional DC/DC converter from Texas Instruments. A transfer efficiency of $90 \%$ is assumed from the datasheet for both directions. The balancing current of the converter is $5 \mathrm{~A}$.

Batch simulations are executed with different battery parameter settings and two different balancing algorithms. Algorithm "Simple" balances only one cell at the same time whereas "Smart" can balance adjacent cell groups according to the description available in Section IV. The arithmetic mean of the 10,000 simulation results is shown in TABLE V. The best values are highlighted in bold letters. Summarising the results, any active balancing method increased the usable capacity of a battery considerably. In terms of overall efficiency and balancing time, there are substantial differences between the investigated methods. The "Smart" algorithm shows the best performance since it balances more than one cell at the same time, if useful. Sorted assembly of the cells in order of their capacity makes only sense if the "Smart" algorithm is used.

Equation (5) defines the mathematical computation of the balancing efficiency as a function of the amount of charge involved in the balancing process $Q_{B a l}$ (sum of total balancing current) and the accumulated losses $Q_{\text {Losses }}$ in the converter and switch-matrix. It depends of the transfer efficiency of the balancing unit, the cell capacity distribution, the position of the cell and the implemented balancing algorithm.

$$
\eta_{\text {Bal }}=1-\frac{\sum Q_{\text {Losses }}}{\sum Q_{\text {Bal }}}
$$

\section{Part count}

Most active balancing topologies use a power electronic converter for each battery cell (or cell level), which transfers the charge between cells or cell and stack. By reducing the number of converters, it is possible to reduce the number of components and thus also the cost. If the savings are spent for the remaining hardware, an increase in efficiency will be achieved. TABLE IV gives an overview of the required components of different balancing methods for a battery system with $n$ cells in series (Data from [4] and [41]).
TABLE IV

COMPONENT LIST FOR SEVERAL ACTIVE BALANCING ARCHITECTURES

\begin{tabular}{|c|c|c|c|c|c|c|}
\hline Architecture & FET & SW & $\overline{\mathrm{R}}$ & $\bar{C}$ & $\overline{\mathrm{L}}$ & $\overline{\mathrm{D}}$ \\
\hline Dissipative (Passive) & 0 & $\mathrm{n}$ & $\mathrm{n}$ & 0 & 0 & 0 \\
\hline PWM Converters & $2 n-2$ & 0 & 0 & 1 & $\mathrm{n}-1$ & 0 \\
\hline Switched capacitors & $2 n$ & 0 & 0 & $\mathrm{n}-1$ & 0 & 0 \\
\hline Single switched capacitor & $2 n$ & 0 & 0 & 1 & 0 & 0 \\
\hline Step up converter & $\mathrm{n}$ & 0 & 0 & $\mathrm{n}$ & $\mathrm{n}$ & $\mathrm{n}$ \\
\hline $\begin{array}{l}\text { Multiple transformer } \\
\text { (Cell-to-Stack) }\end{array}$ & $\mathrm{n}$ & 0 & 0 & 0 & $\mathrm{n}$ & $\mathrm{n}$ \\
\hline $\begin{array}{l}\text { Multiple transformer } \\
\text { (Stack-to-cell) }\end{array}$ & 1 & 0 & 0 & 0 & $\mathrm{n}$ & $\mathrm{n}$ \\
\hline $\begin{array}{l}\text { Bidirectional multiple } \\
\text { transformer (C2St2C) }\end{array}$ & $2 n$ & 0 & 0 & 0 & $\mathrm{n}$ & 0 \\
\hline $\begin{array}{l}\text { Bidirectional DC/DC with } \\
\text { energy storage (TI Ref.) }\end{array}$ & 2 & $2 n$ & 0 & 0 & 1 & 0 \\
\hline $\begin{array}{l}\text { Bidirectional buck-boost } \\
\text { (This work) }\end{array}$ & 4 & $\mathrm{n}+1$ & 0 & 0 & 1 & 0 \\
\hline
\end{tabular}

For the new method, the amount of high frequency switching devices is four. The MOSFETs of the switch-matrix operate at low frequency, permitting the use of a very low power gate driver (like the HT0440 from Microchip). Compared to most other topologies, also the number of inductive components can be reduced significantly.

\section{System simulation results}

The system simulation output depends strongly on the battery cell parameters. Therefore, the simulation result is used for demonstration purposes and to verify the numerical simulation in the given operating point. A battery system similar to the one in Section IV is assumed. Fig. 7 shows the balancing process of eight cells with battery cell capacities between $46 \%$ and $52 \%$ of $C_{n o m}$ running with the "Simple" algorithm. The cell SoC lines show the same behavior as in Fig. 6, which is the output of the numerical simulation.

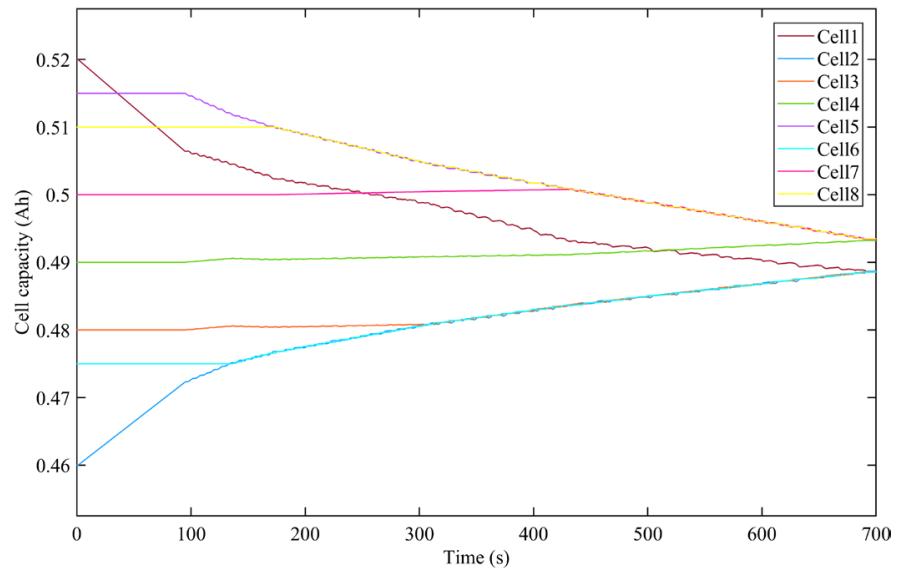

Fig. 7. PLECS simulation output of the balancing process of eight cells for "Simple" algorithm

TABLE V

PERFORMANCE COMPARISON WITH ACTIVE AND PASSIVE BALANCING (EIGHT CELLS, NORMALLY DISTRIBUTED, $\sigma_{0}=2 \%$, AVERAGE OF 10,000 SIMULATIONS)

\begin{tabular}{|c|c|c|c|c|c|c|c|c|}
\hline Balancing method & This work & This work & This work & This work & This work & This work & Cell-to-cell & Passive \\
\hline Balancing algorithm & Simple & Smart & Simple & Smart & Simple & Smart & $\mathrm{n} / \mathrm{a}$ & $\mathrm{n} / \mathrm{a}$ \\
\hline Avg. balancing time $t_{B a l ~ A v g}$ & $672 \mathrm{~s}$ & $529 \mathrm{~s}$ & $815 \mathrm{~s}$ & $345 \mathrm{~s}$ & $886 \mathrm{~s}$ & $359 \mathrm{~s}$ & $838 \mathrm{~s}$ & $2.85 \mathrm{~h}$ \\
\hline Max. balancing time $t_{B a l}$ Max & $1957 \mathrm{~s}$ & $1511 \mathrm{~s}$ & $2447 \mathrm{~s}$ & $1162 \mathrm{~s}$ & $2815 \mathrm{~s}$ & $1373 \mathrm{~s}$ & $2041 \mathrm{~s}$ & $4.43 \mathrm{~h}$ \\
\hline Usable capacity of $C_{n o m}$ & $99.6 \%$ & $99.6 \%$ & $99.6 \%$ & $99.7 \%$ & $99.5 \%$ & $99.6 \%$ & $99.6 \%$ & $97.2 \%$ \\
\hline
\end{tabular}




\section{E. Comparison of simulation and measurement}

These measurements were performed with $\mathrm{LiFePO}_{4}$ cells with a nominal capacity of $10.6 \mathrm{Ah}$. The battery configuration is $8 \mathrm{~S} 1 \mathrm{P}$, the battery is fully charged with two cells having a reduced capacity of $95 \%$ (Cell 3 ) and 78\% respectively (Cell 4). To demonstrate the working principle of the new balancing method, a constant current discharge cycle of 1C (10 A) was applied. The amount of balancing operations was reduced compared to the method description in Section IV.
The measurement is compared to a PLECS simulation featuring the described balancing method and assuming an average efficiency of the DC/DC converter including switchmatrix losses of 94\%. Its output is available in Fig. 8 and Fig. 9. The two subfigures show the cell voltages on the left (a) side and the cell SoC values on the right side (b). The measurement results are shown in Fig. 10, on the left side without balancing and on the right with active balancing enabled. As expected, without balancing, the end of the discharge process is (a)

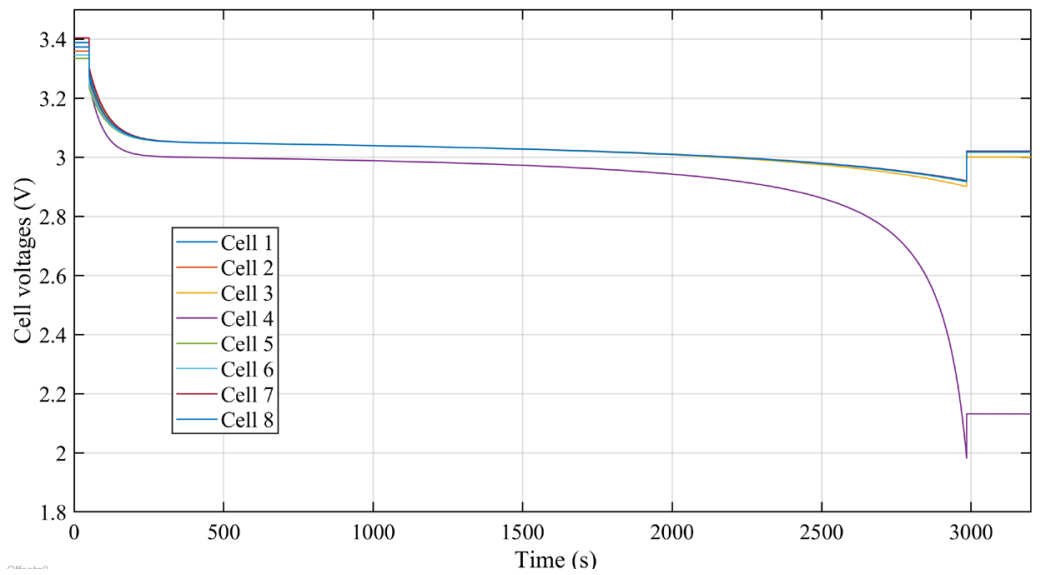

(b)

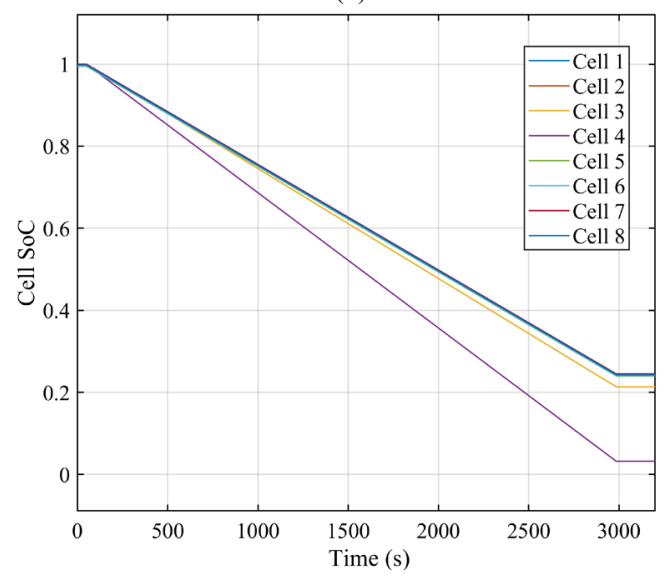

Fig. 8. Simulation of discharge process for an eight-cells battery system without balancing (Discharge current $1 \mathrm{C}=10 \mathrm{~A})$ : Cell voltages (a) and SoC (b)

(a)

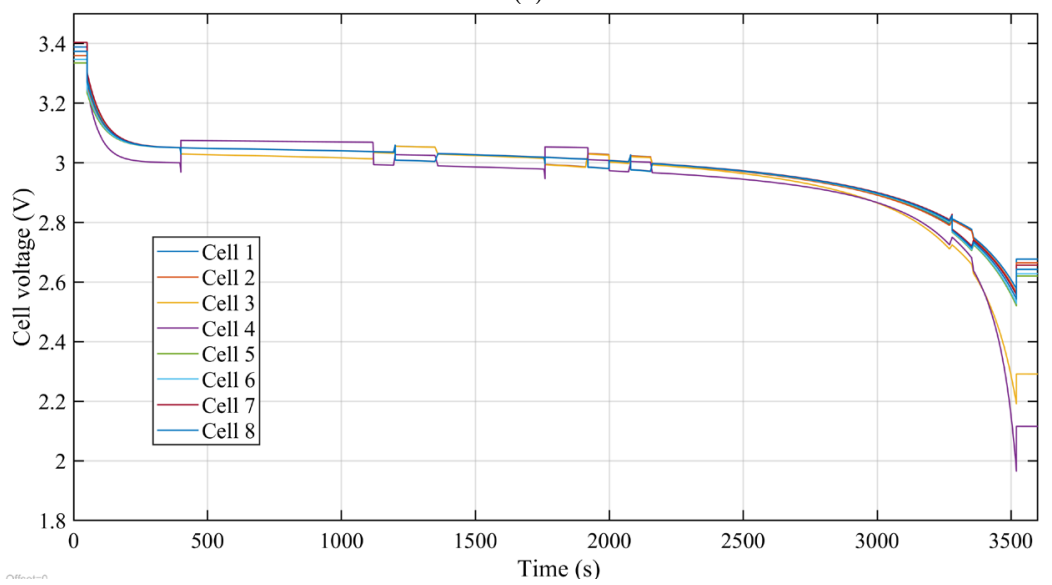

(b)

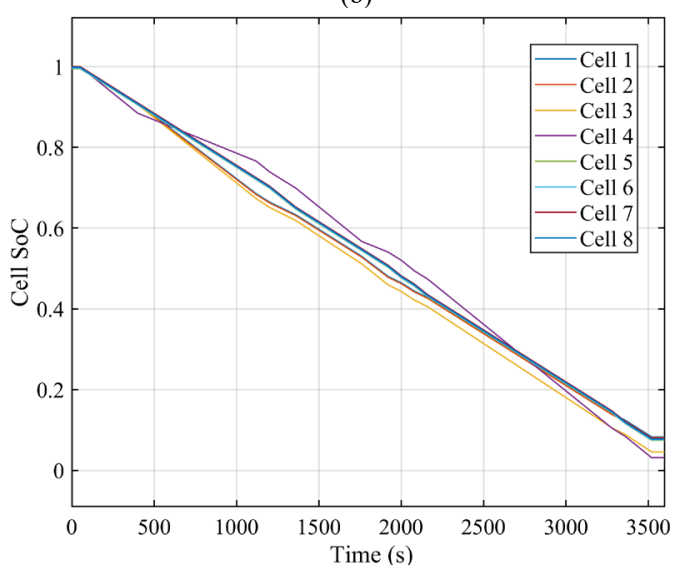

Fig. 9. Simulation of discharge process for an eight-cells battery system with $5 \mathrm{~A}$ active balancing (Discharge current $1 \mathrm{C}=10 \mathrm{~A}$ ): Cell voltages (a) and SoC (b)

(a)

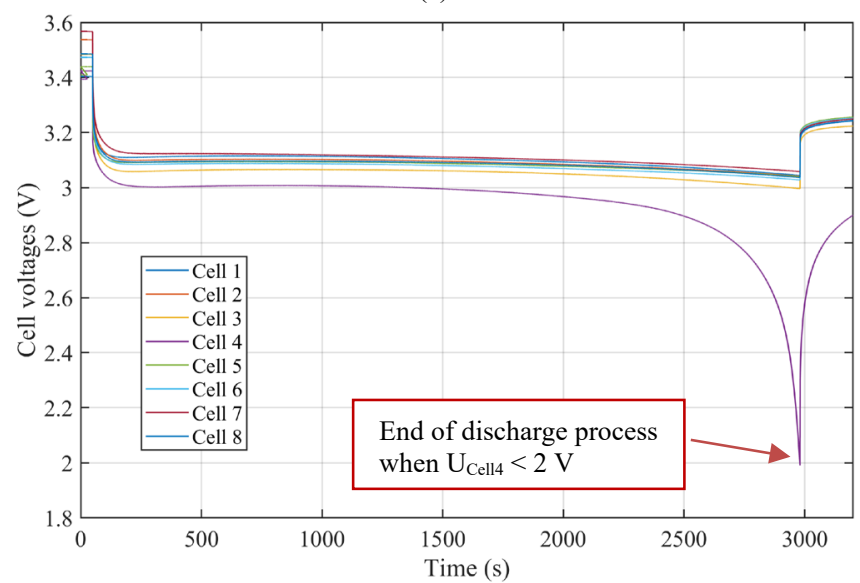

(b)

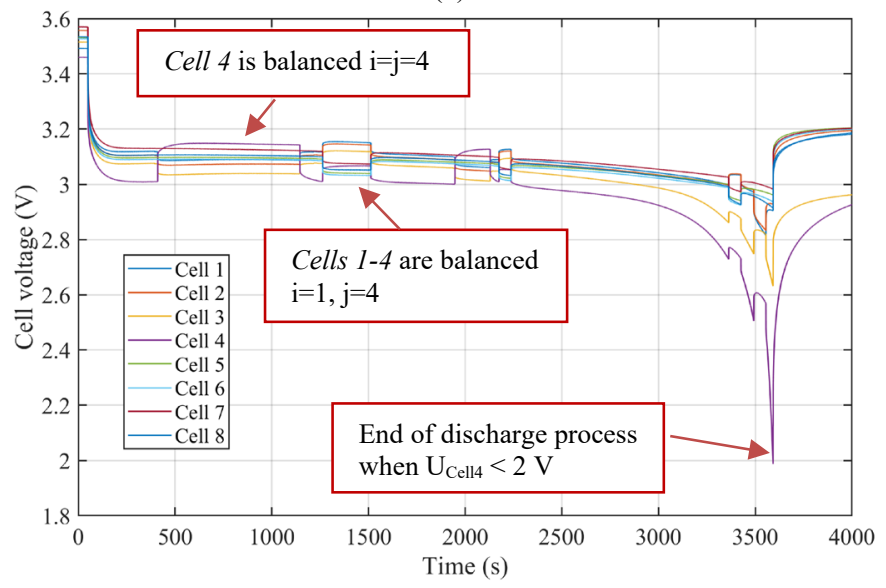

Fig. 10. Measurement of discharge process of an eight-cells battery system without balancing (a) and with active balancing (b) (Discharge current $1 \mathrm{C}=10 \mathrm{~A})$ 
determined by the cell with the reduced SoH. For active balancing, the balancing circuit is able to adjust the $\mathrm{SoC}$ values and therefore the cell voltages of all cells with just five to six balancing interactions. For the given setup, active balancing increases the usable battery capacity by $20.9 \%$, which is more than the calculated gain. The reduced current in the balanced cell probably leads to a higher discharge capacity.

Simulation and measurement deliver consistent voltage curves, the deviation concerning usable battery capacity is less than $3 \%$. The full comparison including the theoretic values from the MATLAB calculation is given in TABLE VI. $C_{A c t}$ and $C_{\text {Pass }}$ are defined as the usable capacity of the battery system for active or passive balancing.

TABLE VI

PERFORMANCE COMPARISON OF SIMULATION AND MEASUREMENT $\left(\mathrm{LIFEPO}_{4}\right)$

\begin{tabular}{|c|c|c|c|}
\hline $\begin{array}{l}\text { Parameter/ } \\
\text { Settings }\end{array}$ & $\begin{array}{c}\text { Calculation } \\
\text { Passive / Active }\end{array}$ & $\begin{array}{c}\text { Simulation } \\
\text { Passive / Active }\end{array}$ & $\begin{array}{l}\text { Measurement } \\
\text { Passive / Active }\end{array}$ \\
\hline $\begin{array}{l}\text { Discharge } \\
\text { time } t_{D i s}\end{array}$ & n.a. & $2931 \mathrm{~s} \quad 3458 \mathrm{~s}$ & $2928 \mathrm{~s} \quad 3536 \mathrm{~s}$ \\
\hline $\begin{array}{l}\text { Discharge } \\
\text { capacity } C_{D i s}\end{array}$ & $8.3 \mathrm{Ah} 9.8 \mathrm{Ah}$ & $8.1 \mathrm{Ah} 9.6 \mathrm{Ah}$ & 8.1 Ah $9.8 \mathrm{Ah}$ \\
\hline $\begin{array}{l}\text { Capacity gain } \\
1-C_{A c t} / C_{\text {Pass }}\end{array}$ & $19.2 \%$ & $18.5 \%$ & $20.9 \%$ \\
\hline
\end{tabular}

\section{F. Measurement of balancing process in idle state}

Another measurement was performed with an eight cells lithium-ion battery $\left(C_{n o m}=12 \mathrm{Ah}, \mathrm{SoH}=100 \%\right)$ to demonstrate the balancing process in idle state. Unlike $\mathrm{LiFePO}_{4}$ as in Section $E$, lithium-ion cells were used. The reason is the flat $\mathrm{C}$ $\mathrm{V}$ characteristics of $\mathrm{LiFePO}_{4}$, which makes it almost impossible to distinguish cell voltages with $\mathrm{SoC}$ differences of only a few percent.

First, the unbalanced cell voltages were measured $\left(U_{0}\right)$ and used to calculate the $\mathrm{SoC}$ of each cell $\left(\mathrm{SoC}_{0}\right)$ based on its opencircuit-voltage (OCV) curve. From this calculation, the mean value of the available cell capacities $\mu_{0}$ and the standard deviation $\sigma_{0}$ were determined:

$\overrightarrow{U_{0}}=\left(\begin{array}{l}3.702 \\ 3.704 \\ 3.736 \\ 3.745 \\ 3.756 \\ 3.750 \\ 3.773 \\ 3.779\end{array}\right) V, \overrightarrow{S o C_{0}}=\left(\begin{array}{l}0.606 \\ 0.609 \\ 0.646 \\ 0.656 \\ 0.669 \\ 0.662 \\ 0.689 \\ 0.696\end{array}\right), \mu_{0}=7.85 \mathrm{Ah}, \sigma_{0}=3.30 \%$

The cell voltages during balancing are shown in Fig. 11. A sequence of several balancing operations leads to a wellbalanced system with all cell voltages being within less than $20 \mathrm{mV}$ after approximately $900 \mathrm{~s}$. The end state $\left(U_{e}\right)$ with the corresponding $S_{o} C_{e}$ vector and $\mu_{e}, \sigma_{e}$ were determined after a relaxation time of two hours.

$$
\overrightarrow{U_{e}}=\left(\begin{array}{l}
3.733 \\
3.735 \\
3.739 \\
3.749 \\
3.733 \\
3.752 \\
3.739 \\
3.745
\end{array}\right) V, \overrightarrow{S o C_{e}}=\left(\begin{array}{l}
0.642 \\
0.645 \\
0.649 \\
0.661 \\
0.642 \\
0.664 \\
0.649 \\
0.656
\end{array}\right), \mu_{e}=7.81 \mathrm{Ah}, \sigma_{e}=0.85 \%
$$

A capacity loss of $40 \mathrm{mAh}$ was measured due to the active balancing. Given the total balancing charge $Q_{B a l}$ of $1.16 \mathrm{Ah}$, this results in a balancing efficiency of $96.5 \%$. The usable capacity has increased by $6 \%$ from $7.27 \mathrm{Ah}$ to $7.70 \mathrm{Ah}$.

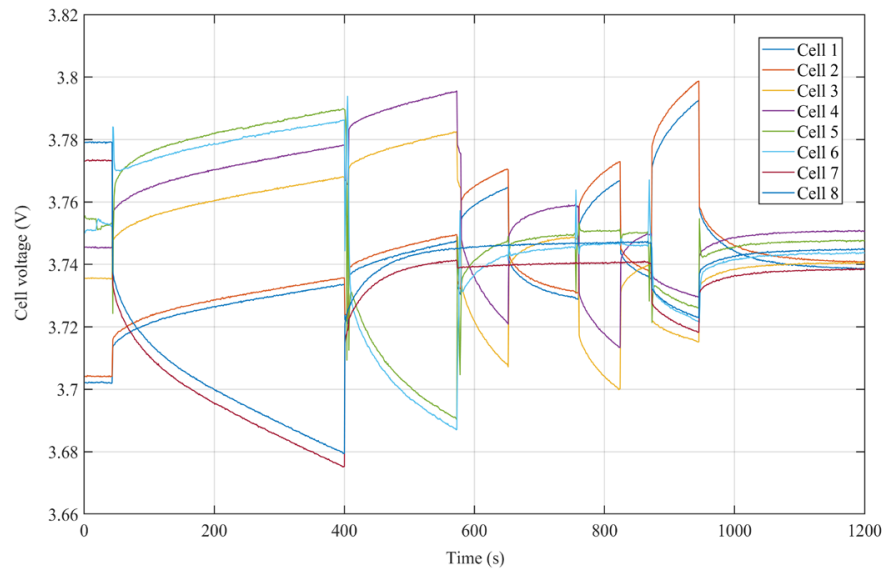

Fig. 11. Measurement of balancing process during idle state for an eight-cells lithium-ion battery system

\section{CONCLUSION}

This paper presents a new approach for active charge balancing. It is the first to propose the combination of a lowspeed switching matrix with a single non-isolated DC/DC converter without the use of external energy tanks such as supercapacitors. It further demonstrates the functionality of the method by means of real measurements. Due to the non-isolated design, a high-efficiency and small size DC/DC-converter can be used and the number of high-speed switching MOSFETs is lower compared to other balancing methods.

The approved, bidirectional converter based active balancing solution TIDA-00817 from Texas Instruments is considered as a reference method. A comparison based on numerical simulations shows an overall reduction in balancing time by $36.9 \%$ for randomly distributed cells. Compared to passive balancing, the equalization time is reduced by a factor of 19.4 and more than $2 \%$ of the battery capacity is extracted on average by the end of the discharge process. The presented method reduces the balancing time during charging and increases the amount of charge that can be extracted from the battery during discharging. A system simulation performed in PLECS demonstrates the working principle. The results for a given operating point are compared to the output of the numerical simulations and verify the correctness of the presented calculations.

Two measurements were made with a hardware prototype using a $5 \mathrm{~A}$ four-switch DC/DC converter. The device was able to balance a battery system consisting of eight $\mathrm{LiFePO}_{4}$ cells during discharge and increase the usable capacity by almost $21 \%$ compared to passive balancing. Additionally, the prototype achieved to balance a lithium-ion battery system within $902 \mathrm{~s}$ from $\Delta \mathrm{SoC}=9 \%$ to $\Delta \mathrm{SoC}=2.2 \%$.

One drawback of the new method is the high-power rating of the converter and its associated losses. For an eight cells battery system and $5 \mathrm{~A}$ of balancing current, the required converter 
power is almost $130 \mathrm{~W}$. The ability to balance neighboring cells simultaneously compensates for part of this disadvantage. Due to the fact, that the number of cells in series affects the overall efficiency and the converter power rating, the presented method is suitable mainly for low-voltage applications. The expected overall efficiency decreases linearly with increasing number of cells in series. For high-voltage battery systems, inter-module balancing could be a solution to transfer charge between battery modules of e.g. 12 to 16 cells in series.

A general disadvantage of active balancing circuits compared to passive balancing is the low-impedance connection to the battery cells. This makes the system susceptible to short-circuits in the event of component failures. As a countermeasure, all battery cell connections are usually equipped with fuses.

\section{REFERENCES}

[1] Yao C. Hsieh, Chin S. Moo, and Wen Y. Ou-Yang, "A Bi-directional Charge Equalization Circuit for Series-connected Batteries," in 2005 International Conference on Power Electronics and Drives Systems, Kuala Lumpur, Malaysia, 2005, vol. 2, pp. 1578-1583.

[2] Juan Zhao, Jiuchun Jiang, and Liyong Niu, "A novel charge equalization technique for electric vehicle battery system," in The Fifth International Conference on Power Electronics and Drive Systems, 2003. PEDS 2003., Singapore, 2003, vol. 2, pp. 853-857.

[3] A. C. Baughman and M. Ferdowsi, "Double-Tiered SwitchedCapacitor Battery Charge Equalization Technique," IEEE Trans. Ind. Electron., vol. 55, no. 6, pp. 2277-2285, Jun. 2008.

[4] J. Gallardo-lozano, E. Romero-cadaval, M. I. Milanes-montero, and M. A. Guerrero-martinez, "Battery equalization active methods," J. Power Sources, vol. 246, pp. 934-949, 2014.

[5] M. Caspar, T. Eiler, and S. Hohmann, "Systematic Comparison of Active Balancing: A Model-based Quantitative Analysis," IEEE Trans. Veh. Technol., 2016.

[6] M. Daowd, N. Omar, P. Van Den Bossche, and J. Van Mierlo, "A review of passive and active battery balancing based on MATLAB/Simulink," J Int Rev Electr Eng, vol. 6, pp. 2974-2989, 2011.

[7] F. Baronti, R. Roncella, and R. Saletti, "Performance comparison of active balancing techniques for lithium-ion batteries," J. Power Sources, vol. 267, pp. 603-609, Dec. 2014.

[8] M. Preindl, C. Danielson, and F. Borrelli, "Performance evaluation of battery balancing hardware," in Control Conference (ECC), 2013 European, 2013, pp. 4065-4070.

[9] A. Ziegler, D. Oeser, B. Arndt, and A. Ackva, "Comparison of Active and Passive Balancing by a Long Term Test Including a Post-Mortem Analysis of all Single Battery Cells," in 2018 International IEEE Conference and Workshop in Óbuda on Electrical and Power Engineering (CANDO-EPE), Budapest, 2018, pp. 000015-000020.

[10] W. C. Lee, D. Drury, and P. Mellor, "Comparison of passive cell balancing and active cell balancing for automotive batteries," in Vehicle Power and Propulsion Conference (VPPC), 2011 IEEE, 2011, pp. 1-7.

[11] D. Cadar, D. Petreus, T. Patarau, and N. Palaghita, "Active balancing method for battery cell equalization," Acta Tech. Napoc., vol. 51, no. 2, p. 1,2010 .

[12] J. Xu, S. Li, C. Mi, Z. Chen, and B. Cao, "SOC Based Battery Cell Balancing with a Novel Topology and Reduced Component Count," Energies, vol. 6, no. 6, pp. 2726-2740, May 2013.

[13] M. Lukasiewycz, M. Kauer, and S. Steinhorst, "Synthesis of Active Cell Balancing Architectures for Battery Packs," IEEE Trans. Comput.Aided Des. Integr. Circuits Syst., vol. 35, no. 11, pp. 1876-1889, Nov. 2016.

[14] Steinhorst, Sebastian and M. Lukasiewycz, "Formal Approaches to Design of Active Cell Balancing Architectures in Battery Management Systems," presented at the 2016 IEEE/ACM International Conference on Computer-Aided Design (ICCAD), Austin, TX, USA, 2016.

[15] V. Muenzel, J. de Hoog, M. Brazil, D. a. Thomas, and I. Mareels, "Battery Management using Secondary Loads: A Novel Integrated Approach," in IFAC Proceedings Volumes, 2014, vol. 47, no. 3, pp. 3924-3929.
[16] N. Dahan, M. M. Peretz, and I. Zeltser, "Cell-level hybrid architectures for active balancing of serially-connected batteries," in Applied Power Electronics Conference and Exposition (APEC), 2017 IEEE, 2017, pp. 2382-2389.

[17] Z. Shen, H. Gui, and L. M. Tolbert, "A battery cell balancing control scheme with minimum charge transfer," in Energy Conversion Congress and Exposition (ECCE), 2016 IEEE, 2016, pp. 1-8.

[18] S. Shah, M. Murali, and P. Gandhi, "A Practical Approach of Active Cell Balancing in a Battery Management System," in 2018 IEEE International Conference on Power Electronics, Drives and Energy Systems (PEDES), Chennai, India, 2018, pp. 1-6.

[19] F. Baronti, G. Fantechi, R. Roncella, and R. Saletti, "High-Efficiency Digitally Controlled Charge Equalizer for Series-Connected Cells Based on Switching Converter and Super-Capacitor," IEEE Trans. Ind. Inform., vol. 9, no. 2, pp. 1139-1147, May 2013.

[20] D. F. Frost and D. A. Howey, "Completely Decentralized Active Balancing Battery Management System," IEEE Trans. Power Electron., vol. 33, no. 1, pp. 729-738, Jan. 2018.

[21] S. Narayanaswamy, S. Steinhorst, M. Lukasiewycz, M. Kauer, S. Chakraborty, and T. Munich, "Optimal Dimensioning of Active Cell Balancing Architectures," p. 6.

[22] M. Räber, D. O. Abdeslam, A. Heinzelmann, and A. Ramirez, "Performance estimation of a cell-to-cell-type active balancing circuit for lithium-ion battery systems," in Industrial Electronics (ISIE), 2017 IEEE 26th International Symposium, 2017, pp. 1005-1010.

[23] F. Mestrallet, L. Kerachev, J.-C. Crebier, and A. Collet, "Multiphase Interleaved Converter for Lithium Battery Active Balancing," IEEE Trans. Power Electron., vol. 29, no. 6, pp. 2874-2881, Jun. 2014.

[24] S.-W. Lee, K.-M. Lee, Y.-G. Choi, and B. Kang, "Modularized Design of Active Charge Equalizer for Li-Ion Battery Pack," IEEE Trans. Ind. Electron., vol. 65, no. 11, pp. 8697-8706, Nov. 2018.

[25] S.-H. Park, T.-S. Kim, J.-S. Park, G.-W. Moon, and M.-J. Yoon, “A new buck-boost type battery equalizer," in Applied Power Electronics Conference and Exposition, 2009. APEC 2009. Twenty-Fourth Annual IEEE, 2009, pp. 1246-1250.

[26] C. Speltino, A. Stefanopoulou, and G. Fiengo, "Cell equalization in battery stacks through State Of Charge estimation polling," in Proceedings of the 2010 American Control Conference, Baltimore, MD, 2010, pp. 5050-5055.

[27] F. Baronti, G. Fantechi, S. Member, R. Roncella, and R. Saletti, "HighEfficiency Digitally Controlled Charge Equalizer for Series-Connected Cells Based on Switching Converter and Super-Capacitor," vol. 9, no. 2, pp. 1139-1147, 2013.

[28] W. Maier, I. C. Bastos, and A. Schmid, "Low-Cost, Precision Battery Management System with Active Balancing up to $\pm 10 \mathrm{~A}$," in PCIM Europe 2014, 2014, p. 8.

[29] X. Cui, W. Shen, Y. Zhang, and C. Hu, "A Fast Multi-Switched Inductor Balancing System Based on a Fuzzy Logic Controller for Lithium-Ion Battery Packs in Electric Vehicles," Energies, vol. 10, no. 7, p. 1034, Jul. 2017.

[30] P. A. Cassani and S. S. Williamson, "Design, Testing, and Validation of a Simplified Control Scheme for a Novel Plug-In Hybrid Electric Vehicle Battery Cell Equalizer," IEEE Trans. Ind. Electron., vol. 57, no. 12 , pp. $3956-3962$, Dec. 2010.

[31] T. H. Phung, J.-C. Crebier, A. Chureau, A. Collet, and V. Nguyen, "Optimized structure for next-to-next balancing of series-connected lithium-ion cells," in 2011 Twenty-Sixth Annual IEEE Applied Power Electronics Conference and Exposition (APEC), Fort Worth, TX, USA, 2011, pp. 1374-1381.

[32] A. Manenti, A. Abba, A. Merati, S. M. Savaresi, and A. Geraci, "A New BMS Architecture Based on Cell Redundancy," IEEE Trans. Ind. Electron., vol. 58, no. 9, pp. 4314-4322, Sep. 2011.

[33] M. Einhorn et al., "A Current Equalization Method for Serially Connected Battery Cells Using a Single Power Converter for Each Cell," vol. 60, no. 9, pp. 4227-4237, 2011.

[34] M. Einhorn, W. Roessler, and J. Fleig, "Improved Performance of Serially Connected Li-Ion Batteries With Active Cell Balancing in Electric Vehicles," IEEE Trans. Veh. Technol., vol. 60, no. 6, pp. 24482457, Jul. 2011.

[35] Y. Chen, X. Liu, Y. Cui, J. Zou, and S. Yang, "A Multi-winding Transformer Cell-to-Cell Active Equalization Method for Lithium-Ion Batteries with Reduced Number of Driving Circuits," IEEE Trans. Power Electron., pp. 1-1, 2015. 
[36] A. Ramirez and B. Miesch, "BSc Thesis: Active balancing battery management system for a Li-ion battery pack used in an electric vehicle," ZHAW, Winterthur, 2015.

[37] C.-H. Kim, M.-Y. Kim, Y.-D. Kim, and G.-W. Moon, "A modularized charge equalizer using battery monitoring IC for series connected LiIon battery strings in an electric vehicle," presented at the 8th International Conference on Power Electronics - ECCE Asia, 2011, pp. 304-309.

[38] Y. Shang, N. Cui, Q. Zhang, and C. Zhang, "A battery equalizer with zero-current switching and zero-voltage gap among cells based on three-resonant-state LC converters," 2017, pp. 1647-1651.

[39] Holland, Stephen, "16-Cell Lithium-Ion Battery Active Balance Reference Design," p. 17, 2016.

[40] M. Chen and G. A. Rincon-Mora, "Accurate Electrical Battery Model Capable of Predicting Runtime and I-V Performance," IEEE Trans. Energy Convers., vol. 21, no. 2, pp. 504-511, Jun. 2006.

[41] M. Ehsani, Ed., Modern electric, hybrid electric, and fuel cell vehicles: fundamentals, theory, and design. Boca Raton: CRC Press, 2005.

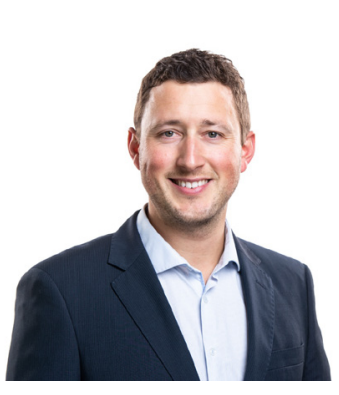

Manuel Raeber (M'12) received his MSc in electrical engineering and information technology from ETH Zurich, Switzerland in 2007 . He holds a $\mathrm{PhD}$ in electrical engineering in 2018 at the University of Haute Alsace UHA in Mulhouse, France and works as a research associate at the University of Applied sciences ZHAW in Winterthur, Switzerland.

His research interests include power electronic converters for the renewable energy, active battery management circuits and algorithms and state-of-charge estimation as well as lifetime behavior of battery cells and systems.

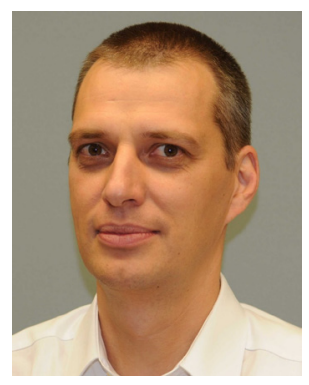

Andreas Heinzelmann received his $\mathrm{PhD}$ in electrical engineering from the University of Paderborn in Paderborn, Germany. He currently works as a professor at the University of Applied Sciences ZHAW in Winterthur, Switzerland. He is head of the research group for power electronics and energy storage systems within the institute for fluid engineering and energy systems

IEFE.

His research interests include measurement and control technology, automated code generation and power electronics.

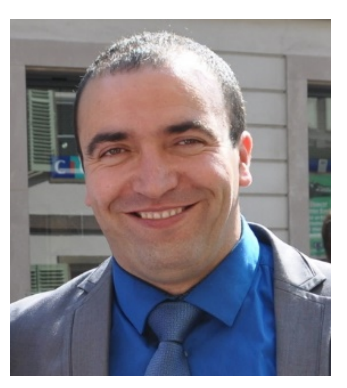

Djaffar Ould Abdeslam (M'08SM'15) received the M.Sc. degree in electrical engineering from the University of Franche-Comté, Besançon, France, in 2002. He received the Ph.D. degree in 2005 and the Habilitation degree in electrical engineering in 2014 from the University of Haute-Alsace, Mulhouse, France. Since 2007, he has been an Associate Professor at the University of Haute-Alsace. His research interest includes artificial neural networks applied to power systems, signal processing for power quality improvement, smart metering, smart building, and smart grids. 